\title{
Modeling and predictive control of InGap/GaAs/Ge triple-junction solar cells to increase the energy conversion efficiency
}

Reza Barati-Boldaji, Sepide Mojalal, Mohammad Reza Seifi

Department of Electrical and Computer Engineering, Science and Research branch, Islamic Azad University, Iran

\begin{tabular}{l}
\hline \hline Article Info \\
\hline Article history: \\
Received Feb 8, 2018 \\
Revised May 29, 2019 \\
Accepted Jun 12, 2019 \\
\hline
\end{tabular}

\section{Keywords:}

Lyapunov theory

Predictive control

Single-phase inverter

Stability

Triple-junction solar cell

\begin{abstract}
Physical studies of the last decade indicate that multi-junction solar cell has higher energy conversion efficiency than single-junction cells. However, choosing the type of material, modeling and finding the parameters of this type of cell has always been one of the leading challenges in this topic. Most of the proposed models are assumed to have predetermined electrical parameters of the cell or regardless of the effect of the tunnel junction, which reduces of the system. This paper discusses the modeling of solar cell triplejunction InGap/GaAs $/ \mathrm{Ge}$, taking into account the effect of a tunnel junction and finds the parameters of each subcellular deal. Also, predictive control will be used to control the active and reactive power of the single-phase inverter. The use of this method eliminates the need for the modulation module and the phase-lock loop (PLL). And simplifies the control algorithm for its digital implementation. The proposed cost function of this paper will be such that in addition to controlling the power of the inverter, the closed loop stability will be guaranteed based on the Lyapunov theory. Finally, the performance of the system using the software MATLAB/SIMULINK simulation will be evaluated.
\end{abstract}

Copyright (C) 2019 Institute of Advanced Engineering and Science. All rights reserved.

\section{Corresponding Author:}

Reza Barati-Boldaji,

Department of Electrical and Computer Engineering,

Science and Research branch, Islamic Azad University,

Daneshgah Blvd, Simon Bulivar Blvd, Tehran, Iran.

Email: reza.ctrll@gmail.com

\section{INTRODUCTION}

The sun's rays are composed of a variety of spectra. Each type of semiconductor can only absorb certain wavelengths depending on the material's material. Accordingly, in the 1991s, triple-junction solar cell composed of InGap/GaAs/Ge (Indium Gallium Phosphide/Gallium Arsenide/Germanium) resulted in a significant increase in energy conversion efficiency relative to conventional silicon cells [1]. These cells are created by joining three alloys from groups III to $\mathrm{V}$ of the periodic table with different energy bands. This makes it possible to absorb wider wavelengths of the solar radiation spectrum and, therefore, have higher energy conversion efficiency than conventional cells.

InGap, having an energy band of 1.86 , GaAs 1.42 and Ge 0.67 electron volts, has three candidates for use in the triple-junction cell, respectively, as the upper, middle and lower layers, which in addition to having an appropriate energy band in terms of distance atomic energy in the crystalline network is also in agreement [2]. However, with increasing number of junction, theoretical efficiency increases, but the biggest challenge that prevents them from choosing material with appropriate and consistent energy band is the physical and high cost of production, which leads to the use of this technology often into triple-junction cells for applications it requires high energy conversion efficiency, such as satellites. Another challenge facing such cells is to model and find electrical parameters. 
The model presented in [1, 3, 4] ignores the effect of the tunnel junction and assumes cell parameters for a specific working condition. Also, in [2], the effect of tunneling junction is considered in modeling but the method of calculation of cell parameters is not mentioned and it is predetermined for a specific working conditions, is considered. Network-connected photovoltaic systems require an inverter to convert DC-AC, whose control stage is often based on a phase-lock loop (PLL), whose design and adjustment of its internal components are facing many challenges [5]. The use of the predictive control method proposed in [6] and [7] has overcome these limitations. However, although the performance of the system may be optimal in the horizon of forecasting but the use of predictive control with progressive vision system may be at risk for closed-loop instability.

This issue becomes more important, especially when there are constraints. Therefore, the design of a cost function that should guarantee a closed loop stability in addition to controlling the output power of the inverter should also be justified. Therefore, in this paper, a triple-junction solar cell is firstly modeled on the effects of tunneling junction, and it is estimated using the voltage-current characteristic of each subcellular parameter. Then, in order to control the active and reactive power, it is proposed to propose a cost function prediction control method that will also ensure stability based on the theory of Lyapunov. Finally, the proposed system performance will be simulated and evaluated.

\section{TRIPLE-JUNCTION CELL MODELING WITH TUNNEL JUNCTION}

\subsection{Tunnel junction model}

A tunnel junction between the two sub-cells helps to achieve low electrical resistance and high optical transmission. The significance of this junction becomes clear when, if neglected, the p-region of the upper subunit directly connects to the n-section of the subcellular region and creates a p-n link in the opposite direction. Current-voltage characteristic tunnel junction to (1) $[1,8]$.

$J_{\text {total }}=\frac{V_{t}}{V_{p}} J_{p} e^{\left(1-\frac{V_{t}}{V_{p}}\right)}+J_{v} e^{A_{2}\left(V_{t}-V_{v}\right)}+J_{s} e^{\left(\frac{q V_{t}}{K T}\right)-1}$

Where $J_{p}$ is the maximum current density, $V_{t}$ is the tunnel junction voltage, $V_{p}$ is the maximum voltage, $J_{v}$ is the minimum current density, $V_{v}$ is the minimum voltage and $A_{2}$ is the excess current density. The nonlinear relationship between the voltage and current of the tunnel junction used in the Triple-junction solar cell is shown in Figure 1 [9].

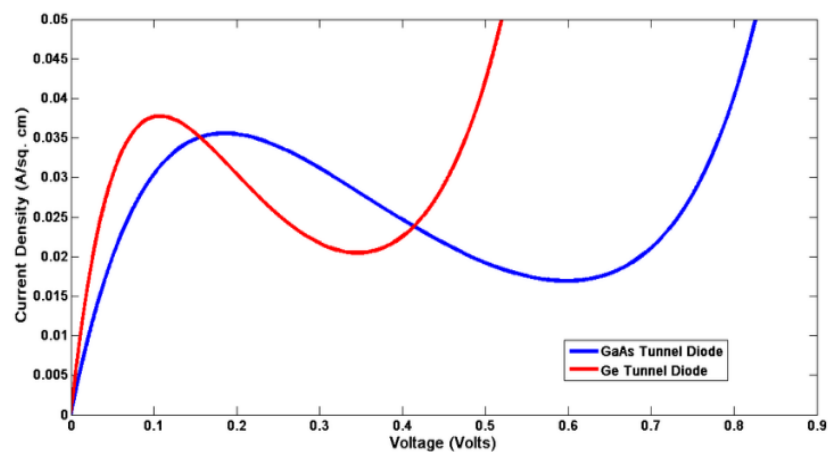

Figure 1. Voltage-current characteristics of a tunnel junction GaAs and Ge

\subsection{Triple-junction solar cell model}

All Figure 2 shows the equivalent electrical circuit of a Triple-junction solar cell, taking into account the effect of the tunnel junction [1]. 


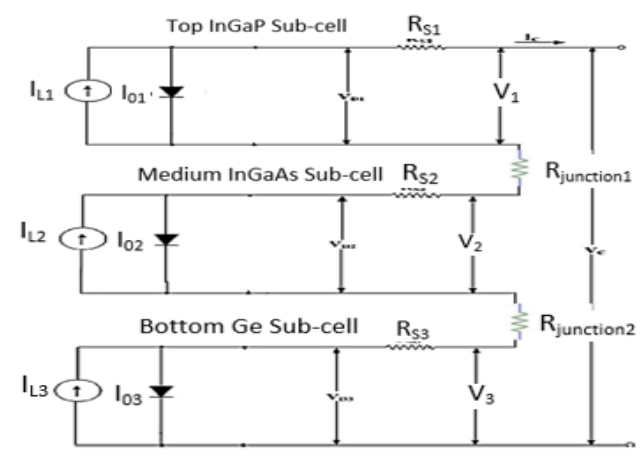

Figure 2. The equivalent electrical circuit of a triple-junction solar cell

In this model, each sub cell acts as a current source and all subcells are connected in series. Therefore, the total current of a three-linked cell is limited to the smallest of these three streams.

$$
I_{s c}=\min \left(I_{s c, t o p}, I_{s c, \text { mi } d}, I_{s c, b o t}\right)
$$

In which $I_{t o p}, I_{m i d}, I_{b o t}$ is the flow of upper, mid, and underlying subcellules. The total cell voltage is also:

$$
V=V_{t o p}-V_{t j 1}+V_{\text {mid }}-V_{t j 2}+V_{b o t}
$$

Where $V_{t o p}, V_{\text {mid }}, V_{b o t}$ have the voltage of the upper, middle, and lower subcellular voltages and $V_{t j 1}, V_{t j 2}$ are the voltages of the first and second tunnel junction. Given the electrical equivalent circuit for each subcell $i=1,2,3$ we can write:

$I_{(i)}=I_{L}(i)-I_{0}(i)\left(e^{\frac{q\left(V(i)-I(i) R_{S}(i)\right)}{n(i) K T}}-1\right)$

The parameters of the above model are:

$V(i)$ is the output voltage of the i-th cell, $I_{L}(i)$ the output current of the i-th cell, $I_{0}(i)$ of the i-th reverse impingement saturation current, $q$ the load of one electron, $n(i)$ of the diode quality of the i-th cell, $K$ Boltzmann's constant, $T$ absolute temperature and $R_{S}(i)$ is the i-th cell resistor. Parallel resistance due to its large size is neglected. According to (4), the proposed model parameters to be estimated are:

$$
\lambda=\left[I_{L}(1), I_{0}(1), R_{S}(1), I_{L}(2), I_{0}(2), R_{S}(2), I_{L}(3), I_{0}(3), R_{S}(3)\right]
$$

\subsection{Estimation of the parameters of the subcellular cells}

The following parameters of each cell based on the voltage-current characteristics of each sub-cell available and can be calculated using a (6-11) Relations. Where $i=1,2,3$ respectively, represents the upper, middle and lower subcellular regions. The first parameter of the model, the radiation current under the i-th subcellular is equal to:

$$
\begin{aligned}
& I_{L}(i)=I_{L\left(T_{1}\right)}(i)\left(1+K_{0}(i)\left(T-T_{1}\right)\right) \\
& K_{0}(i)=\frac{\left(I_{s c\left(T_{2}\right)}(i)-I_{s c\left(T_{1}\right)}(i)\right)}{T_{2}-T_{1}} \\
& I_{L\left(T_{1}\right)}(i)=\frac{G(i) I_{s c(T 1, n o m)}(i)}{G_{(\text {nom })}}
\end{aligned}
$$


The second parameter, the reciprocating saturation current is equal to:

$$
\begin{aligned}
& I_{0}(i)=I_{0\left(T_{1}\right)}(i)\left(\frac{T}{T_{1}}\right)^{\frac{3}{n(i)}} e^{\frac{-q V_{g}(i)}{n(i) K\left(\frac{1}{T}-\frac{1}{T_{1}}\right)}} \\
& I_{0\left(T_{1}\right)}(i)=\frac{I_{s c\left(T_{1}\right)}(i)}{\left(e \frac{q V_{o c\left(T_{1}\right)}(i)}{n(i) K T_{1}}-1\right)}
\end{aligned}
$$

The third parameter, the series resistance, is calculated using the voltage-current characteristic of each subcellular unit:

$$
\begin{aligned}
& R_{S}(i)=-\left.\frac{d V}{d I}\right|_{V_{o c}(i)}-\frac{\frac{n(i) K T}{q}}{I_{0}(i) e^{\frac{q V_{o c}(i)}{n(i) K T}}} \\
& R_{S}(i)=-\left.\frac{d V}{d I}\right|_{V_{o c}(i)}-\frac{\frac{n(i) K T}{q}}{I_{0}(i) e^{\frac{q V_{o c}(i)}{n(i) K T}}}
\end{aligned}
$$

The parameters of the set of relations 6-11 are:

$$
\begin{array}{ll}
T_{1} & : \text { Initial temperature }\left(25+273^{\circ} \mathrm{C}\right) \\
T_{2} & : \text { Secondary temperature }\left(75+273^{\circ} \mathrm{C}\right) \\
I_{s c\left(T_{1}\right)} & : \text { Short circuit current at } 25+273^{\circ} \mathrm{C} \\
I_{s c\left(T_{2}\right)}: & \text { Short circuit current at } 75+273^{\circ} \mathrm{C} \\
G & : \text { Amount of radiation in the sun }\left(1 \text { sun }=1000 \mathrm{w} / \mathrm{m}^{2}\right) \\
V_{o c\left(T_{1}\right)} & : \text { Open circuit voltage at } T_{1} \text { temperature } \\
V_{o c\left(T_{2}\right)}: \text { Open circuit voltage at } T_{2} \text { temperature }
\end{array}
$$

$q$ The load of an electron, $T$ working temperature, $E_{g}$ Energy band, $K$ constant Boltzmann and $n$ are ideal ideals $[10,11]$. Table 1 shows the results of finding the parameters of each subcell at $25^{\circ} \mathrm{C}$ and 1000 watts per square meter radiation.

Table 1. Calculate the Parameters of Each Sub Cell at $25^{\circ} \mathrm{C}$ and Radiation 1000 Watts per Square Meter

\begin{tabular}{cccc}
\hline Variable & $I_{L}$ & $I_{0}$ & $R_{S}$ \\
\hline InGap & 3.80 & $3.6489 \mathrm{e}-05$ & 0.0026 \\
$\mathrm{GaAs}$ & 3.04 & $8.5382 \mathrm{e}-06$ & 0.0041 \\
$\mathrm{Ge}$ & 2.28 & $4.3947 \mathrm{e}-05$ & 0.0027 \\
\hline
\end{tabular}

By specifying the parameters of each subcell, the output stream of each subcell $\left(I_{t o p}, I_{m i d}, I_{b o t}\right)$ can be obtained by the Newton-Raphson recurrence method as follows.

$$
\begin{aligned}
& I(i)_{n+1}=I_{n}(i)-\frac{f\left(I(i)_{n}\right)}{f^{\prime}\left(I(i)_{n}\right)} \\
& f(I(i))=I_{s c}(i)-I(i)-I_{0}(i)\left(e^{q\left(\frac{V(i)-I(i) R_{S}(i)}{n(i) K T}\right)}-1\right)=0
\end{aligned}
$$




\section{SINGLE-PHASE INVERTER OUTPUT POWER CONTROL USING PREDICTIVE \\ CONTROL}

One of the areas in the development of photovoltaic systems is inverters connected to the network. With the advancement of microcontrollers in the last decade, predictive control has also been recognized as a novel method in this regard. Due to the limited number of switching states, it can be widely used in converters $[12,13]$. Single-phase full-bridge inverter connected to the network shown in Figure 3 has four switching is as follows [14].

$$
S=\left\{\left[\begin{array}{l}
0 \\
1 \\
1 \\
0
\end{array}\right],\left[\begin{array}{l}
0 \\
1 \\
0 \\
1
\end{array}\right],\left[\begin{array}{l}
1 \\
0 \\
0 \\
1
\end{array}\right],\left[\begin{array}{l}
1 \\
0 \\
1 \\
0
\end{array}\right]\right\}
$$

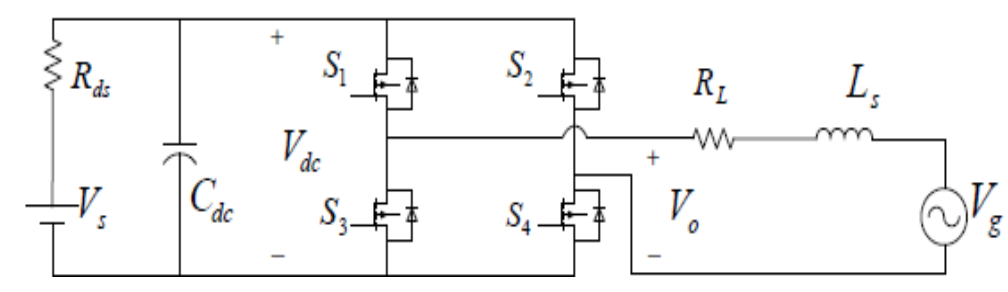

Figure 3. Single-phase full-bridge inverter

The discrete single-phase inverter model is [15]:

$i_{g}(k+1)=\left(1-\frac{T_{s}}{L} R_{e s r}\right) i_{g}(k)+\frac{T_{s}}{L}\left(v_{o}(k)-v_{g}(k)\right)$

Inverter output voltage is a function of switching mode and $V_{d c}$ :

$V_{o}=\left(S_{1} S_{4}-S_{2} S_{3}\right) \times V_{d c}$

The result active and reactive power based on the vertical signal generation Orthogonal Signal Generation (OSG) include:

$$
P=0.5\left(V_{g-\alpha} I_{g-\alpha}+I_{g-\beta}\right)
$$

In which $V_{g-\alpha}$ and $\mathrm{V}_{\mathrm{g}-\beta}$ are output signals of the OSG module with input of $V_{g}, I_{g-\alpha}$ and $I_{g-\beta}$ are output signals of the OSG module with the input of Ig [7, 15]. The next step proposed cost function is active and reactive power output single-phase inverter control and at the same time to guarantee closed loop stability. Given the unlimited horizons in predictive control, it can be ensured by the theory of Lyapunov. It is only necessary to consider the Lyapunov function equal to the cost function of (18) and show $V^{0}(k+1)<V^{0}(k)$ the details of its proof in [13].

$$
V(k)=\sum_{i=1}^{\infty}\|\hat{z}(k+1 \mid k)\|_{Q}^{2}
$$

Also, it's always possible to turn the problem with an infinite horizon into a limited horizontal problem by adding a final cost. Therefore, the expense function with the infinite horizon of the equation (18) can be converted to a function of cost with a finite horizon as (19) [13]. 
$V(k)=\hat{x}\left(k+H_{u} \mid k\right)^{T} \bar{Q} \hat{x}\left(k+H_{u} \mid k\right)+\sum_{i=1}^{\infty}\|\hat{z}(k+1 \mid k)\|_{Q}^{2}$

Where in:

$A^{T} \bar{Q} A=\sum_{i=1}^{\infty}\left(A^{T}\right)^{i} C_{z}^{T} Q C_{z} A^{i}=\bar{Q}-C_{z}^{T} Q C_{z}$

This series is called the Lyapunov matrix equation, and if the system is stable (special values of A within a unit circle), this sum is also limited. Therefore, by placing the matrix A of the discrete model 15 and selecting the weight, $Q>0, \bar{Q}>0$ can be calculated. According to the formulation proposed, it can be concluded that the cost function ensures the stability of the general form of relationship is 19 . Considering active and reactive power as controlled outputs $(z), Q>0$ and control curve $H_{u}=1$, the proposed cost function for active and reactive power control of a single-phase inverter that guarantees stability is:

$V(k+1)=\hat{I}_{g}(k+1 \mid k)^{T} \bar{Q}_{g}(k+1 \mid k)+\left\|P(k+1)-P_{r e f}(k+1)\right\|_{q_{1}}^{2}+\left\|Q(k+1)-Q_{r e f}(k+1)\right\|_{q_{2}}^{2}$

\section{SIMULATION RESULTS}

Suggested photovoltaic solar cell system consists of triple-junction and single-phase inverter controlled by predictive control software using MATLAB / Simulink simulation. The system parameters are given in Table 2. In order to increase the energy conversion efficiency, a triple-junction solar cell is used instead of the common silicon cell, which compares the power-voltage characteristic of the triple-junction cell-current-voltage characteristic to the single-junction cell in a radiation of $1000 \mathrm{w} / \mathrm{m}^{2}$ and a temperature of $25{ }^{\circ} \mathrm{C}$ the ordering is shown in Figures 4 and 5. According to the characteristics, the open circuit voltage of the triple-junction cell is greater than the single-junction cell voltage. Also, the maximum power in the triplejunction cell is about 2.22 times the single-junction common cell.

Table 2. System Parameters

\begin{tabular}{cc}
\hline Switching frequency & $5 \mathrm{KHZ}$ \\
Sampling time & $10 \mu \mathrm{s}$ \\
Ohmic load & $10 \mathrm{ohm}$ \\
Capacitance & $470 \mu \mathrm{F}$ \\
\hline
\end{tabular}

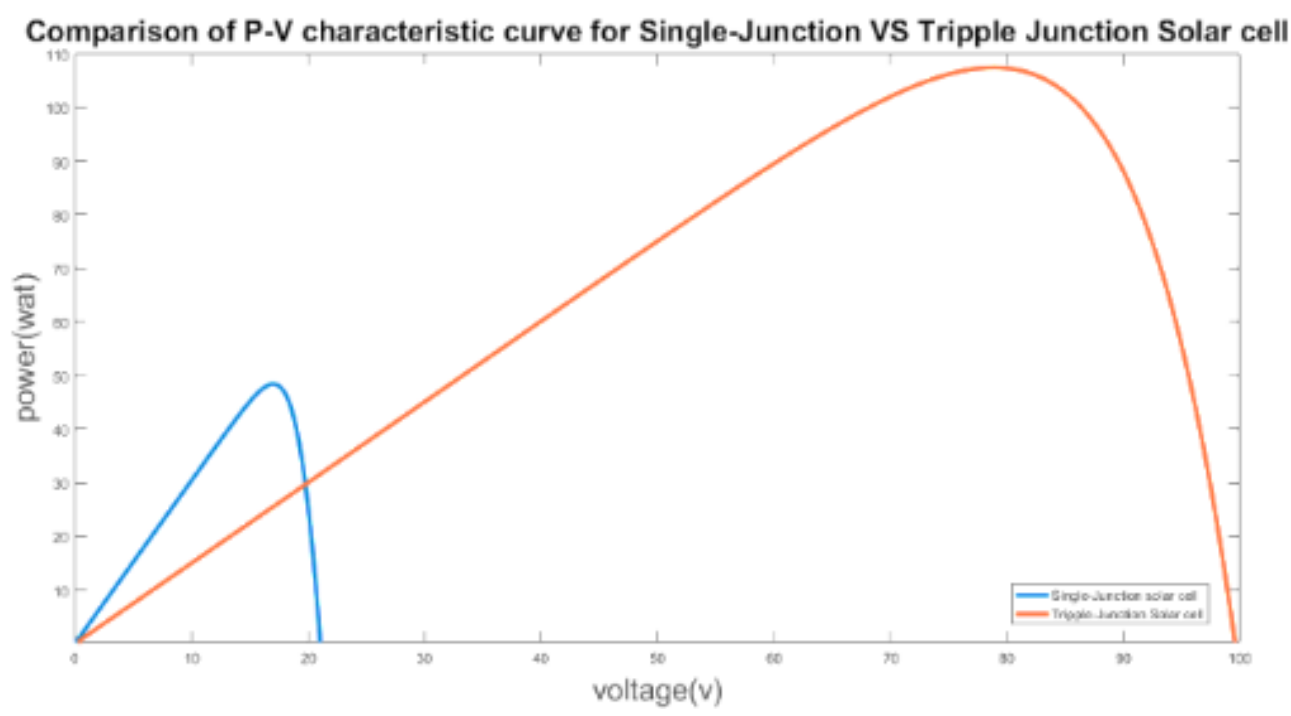

Figure 4. Comparison of the power-voltage characteristic of the triple-junction and single-junction cell in a radiation of 1000 and a temperature of $25^{\circ} \mathrm{C}$ 
Comparison of I-V characteristic curve for Single-Junction VS Tripple Junction Solar cell

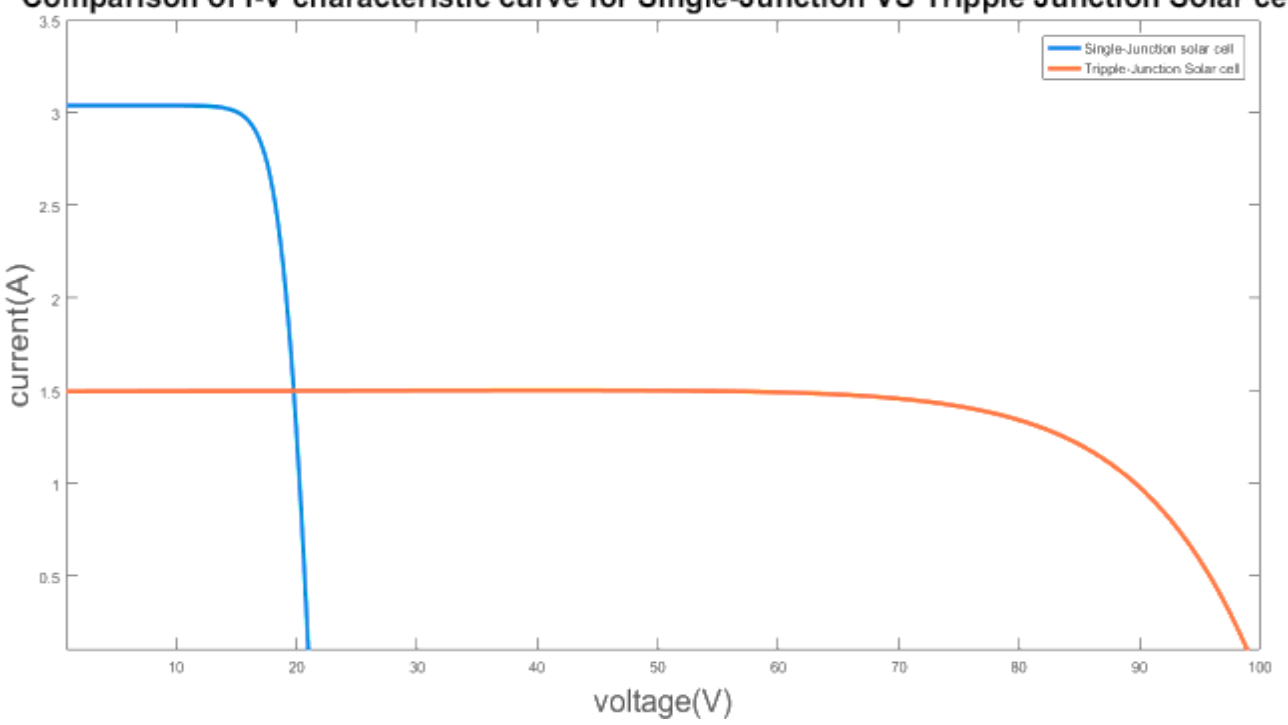

Figure 5. Comparison of the current -voltage characteristic of the triple-junction and single-junction cell in a radiation of 1000 and a temperature of $25^{\circ} \mathrm{C}$

The behavior of the radiation profile system is shown in Figure 6 as an input to the solar cell, which changes at $0.3,0.4,0.7$ (s). Figure 7 and 8 show the voltage and current of the network and Figure 9 and 10 represent active and reactive power in which the reactive power reference is zero and the active power reference is equal to the maximum power point. Advantage of the proposed method is to respond quickly to a steady state and at the same time guarantee the stability of the closed loop. According to Figure 11, the proposed cost function of this paper $V(t)$ is exponentially limited and the closed loop system is stable.

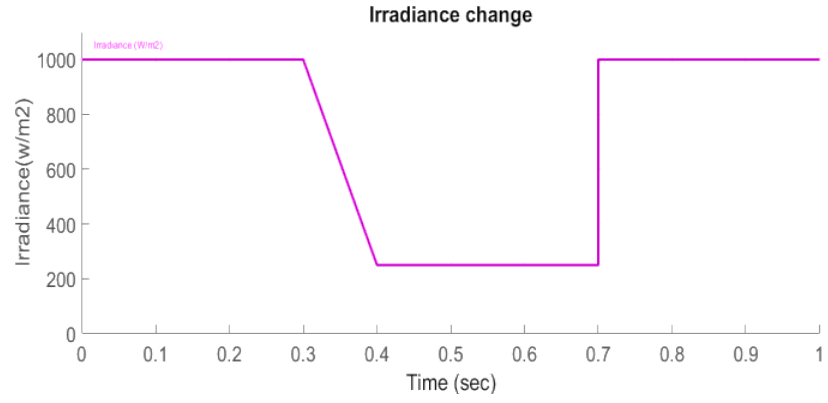

Figure 6. Radiation changes

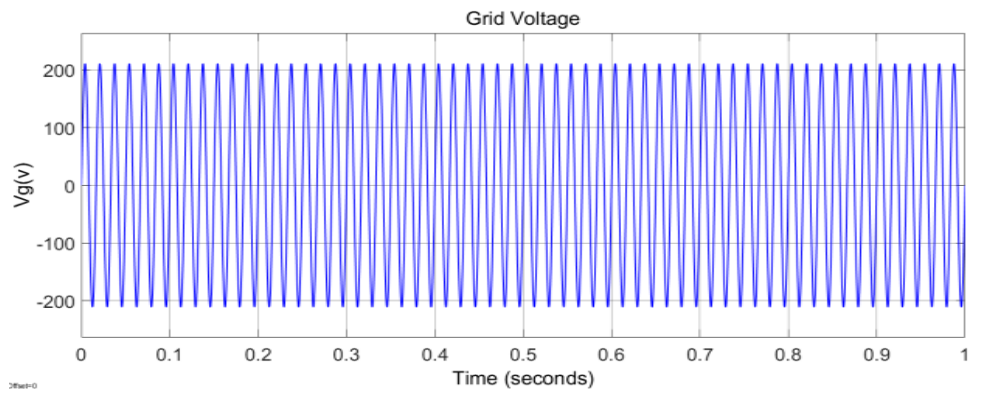

Figure 7. Voltage network 


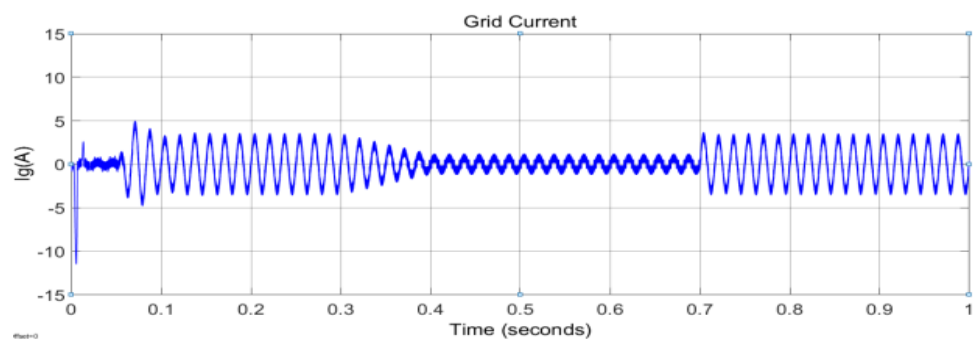

Figure 8. Current network

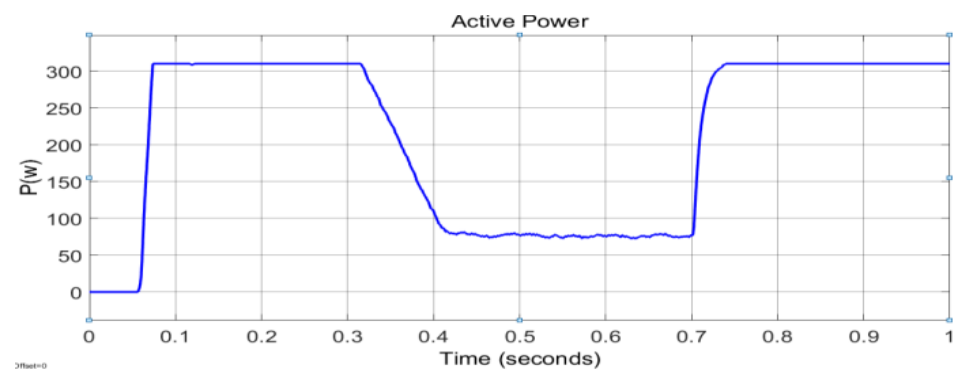

Figure 9. Active power

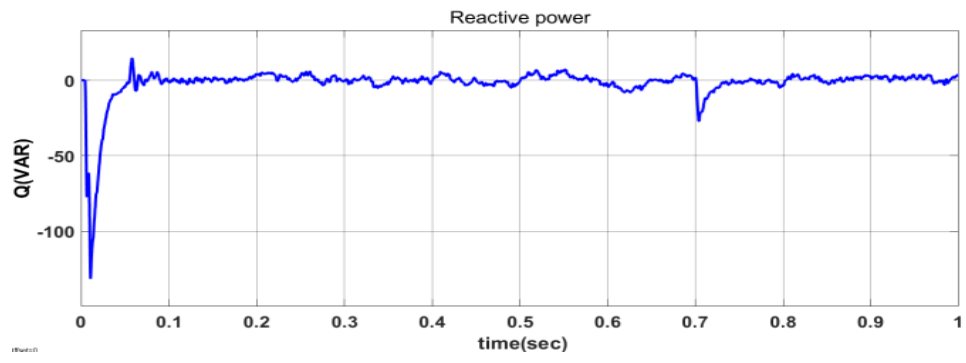

Figure 10. Reactive power

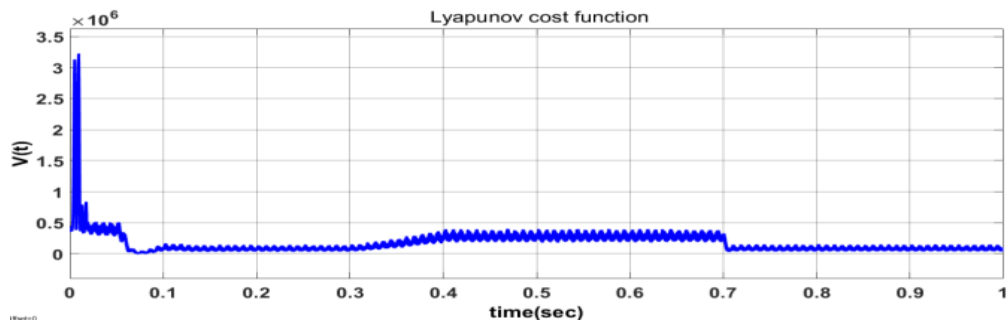

Figure 11. The cost function (Lyapunov)

\section{CONCLUSION}

In this paper, the modeling of triple-junction cells with the consideration of the effect of tunnel transplantation, as well as the calculation of its subcellular parameters, was then compared and then its performance with single-junction cells was compared. In addition, with the goal of removing the phase lock loop (PLL) and simplifying the single-phase inverter control algorithm, a predictive control was used to control the photovoltaic ac system power. In order to avoid the instability of the closed loop system, in this paper, the cost function was proposed based on the formulation of the unlimited horizons. The closed-loop stability of the system is proved by the Lyapunov theory and then the accuracy of the results is determined by simulation. 


\section{REFERENCES}

[1] N. Das, H. Wongsodihardjo, and S. Islam, "Modeling of multi-junction photovoltaic cell using MATLAB/Simulink to improve the conversion efficiency," Renewable Energy, vol. 74, pp. 917-924, 2015/02/01/ 2015.

[2] T. Akter, M. Z. E. Rafique, M. S. Hasan, M. Rafiqul, I. M. M. Islam, and A. Alshareef, "InxGa1-xN-based Multijunction Solar Cell: Modeling and performance Analysis using MATLAB/SIMULINK," in 3rd International Conference on Energy Systems and Technologies, Cairo, 2015.

[3] M. Thakur and B. Singh, "A MATLAB/Simulink Modal of Triple-Junction Solar Cell and MPPT Based on Incremental Conductance Algorithm for PV System," International Journal of Engineering Research and Applications, vol. 5, no. 9, pp. 92-95, 2015.

[4] H. Rezk and E.-S. Hasaneen, "A new MATLAB/Simulink model of triple-junction solar cell and MPPT based on artificial neural networks for photovoltaic energy systems," Ain Shams Engineering Journal, vol. 6, no. 3, pp. 873$881,2015$.

[5] N. Moehle, "Value Function Approximation for Direct Control of Switched Power Converters," arXiv preprint arXiv:1601.05115, 2016

[6] P. E. Kakosimos and A. G. Kladas, "Implementation of photovoltaic array MPPT through fixed step predictive control technique," Renewable energy, vol. 36, no. 9, pp. 2508-2514, 2011.

[7] M. B. Shadmand, X. Li, R. S. Balog and H. A. Rub, "Model predictive control of grid-tied photovoltaic systems: Maximum power point tracking and decoupled power control," 2015 First Workshop on Smart Grid and Renewable Energy (SGRE), Doha, 2015, pp. 1-6.

[8] M. BABAR, S. Q. ALI, and E. A. AL-AMMAR, "Modeling of Tunnel Junction of Multi-junction Solar Cell," Recent Researches in Energy. Environment and Sustainable Development, 2012, pp. 20-24.

[9] M. Babar and E. A. Al-Ammar, "Simulation and modeling of multi-junction solar cell for concentrated photovoltaics using MATLAB/Simulink," Recent Advances in Energy, Environment and Development, pp. 36, 2013.

[10] J. Li and H. Wang, "Maximum power point tracking of photovoltaic generation based on the fuzzy control method," 2009 International Conference on Sustainable Power Generation and Supply, Nanjing, 2009, pp. 1-6.

[11] G. Walker, "Evaluating MPPT converter topologies using a MATLAB PV model," Journal of Electrical \& Electronics Engineering, Australia, vol. 21, no. 1, p. 49, 2001.

[12] Y. Elthokaby, A. L. Elshafei, N. Abdel-Rahim and E. S. Abdel-Aliem, "Finite-control set model-predictive control for single-phase voltage-source UPS inverters," 2016 Eighteenth International Middle East Power Systems Conference (MEPCON), Cairo, 2016, pp. 261-265.

[13] J. M. Maciejowski, Predictive control: with constraints. Pearson education, 2002.

[14] W. Li and X. He, "Review of nonisolated high-step-up DC/DC converters in photovoltaic grid-connected applications," IEEE Transactions on Industrial Electronics, vol. 58, no. 4, pp. 1239-1250, 2011.

[15] Y. Liu, B. Ge, H. Abu-Rub, H. Sun, F. Z. Peng, and Y. Xue, "Model predictive direct power control for active power decoupled single-phase quasi-Z-source inverter," IEEE Transactions on Industrial Informatics, vol. 12, no. 4, pp. 1550-1559, 2016.

\section{BIOGRAPHIES OF AUTHORS}

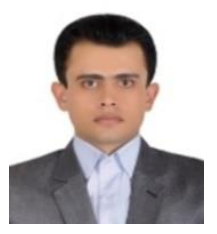

Reza Barati-Boldaji received the B.Eng degree in electrical engineering from Islamic Azad University, Khomeinishahr Branch in 2015. At present, he is the M.Sc student in Islamic Azad University, Science and Research Branch. His current research interests involve the control theory especially PID controllers design and renewable energy. His favorite field of system optimization, fault detection and isolation in wind turbines. His research activities include the improve wind turbine efficiency in icing and de-icing conditions.

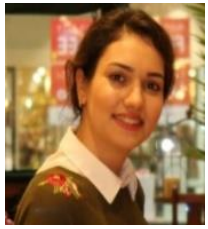

Sepide Mojalal graduated in 2015 with a B.Eng in electrical engineering - Telecommunication. She holds M.S.c degree in Control and automation from SRBIAU, Tehran-Iran in 2018. Her research interests include fault detection and diagnosis and optimization. Currently, her research covers on smart cities with a focus on optimizing the efficiency of renewable energies.

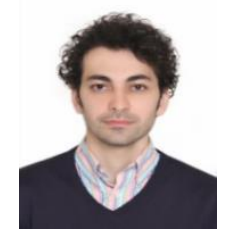

Mohammad Reza Seifi received the B.Eng degree from Islamic Azad University of Arak in 2016 in Electronic engineering. In $2018 \mathrm{He}$ received his M.Sc Degree at Islamic Azad University, Science and Research Branch, Tehran, in Control engineering and did research on congestion control in computer networks. He currently continues researching on other field include computer networks and Renewable energy. 